Acta vet. scand. $1978,19,317-330$.

From the State Veterinary Medical Institute, Helsinki, Finland.

\title{
AN EPIDEMIC OF SALMONELLA INFANTIS INFECTION IN FINNISH BROILER CHICKENS IN $1975-76^{*}$
}

By

M. Raevuori, E. Seuna and E. Nurmi

RAEVUORI, M., E. SEUNA and E. NURMI: An epidemic of Salmonella infantis infection in Finnish broiler chickens in 1975-76. Acta vet. scand. 1978, 19, 317-330. - A large S. infantis infection epidemic in broiler chickens was studied during a period of one year. The outbreak affected three broiler producing companies in Finland. The infection spread to breeding farms according to available data during the summer of 1975 . The epidemic still prevailed at the end of the studies on the farms of certain companies.

The origin of the infection and the means of its spreading could not be ascertained. Some epidemiological evidence suggesting that a hatchery might have spread the infection was found. Contaminated feed may also have been involved, although the findings do not support feed as the principal vehicle in the epidemic. A complex pattern of transmission is most probable.

A microbiological preventive method based on the feeding of a culture of intestinal flora of adult chickens to newly hatched broiler chickens was used on many farms in the study. The feeding of the culture lowered the proportion of infected flocks on the farms and significantly lowered the number of infected birds in those flocks, where the prevention was not complete.

Salmonella infantis; infection; epidemic; broiler chi cken.

In the year 1975 a large epidemic of Salmonella infantis infection occurred on Finnish broiler farms. The organism was detected in flocks belonging to four of the five broiler breeding companies in Finland. Simultaneously an epidemic of S. typhimurium var. copenhagen infection occurred on the farms of the fifth company. This outbreak remained a separate problem af-

* Financially supported by the Food Research Foundation, Helsinki, Finland. 
fecting that particular company and has been described earlier (Seuna et al. 1978). No reported outbreaks of human salmonellosis due to $\mathrm{S}$. infantis occurred during the one year of this study, July 1, 1975-June 30, 1976. Some sporadic cases were observed. Since this period, however, various epidemics due to infected broilers have occurred in humans.

A microbiological preventive method was developed at the State Veterinary Medical Institute, in the course of the studies precipitated by a previous epidemic of salmonella infection in broiler chickens in 1971 (Nurmi \& Rantala 1973, Rantala \& Nurmi 1973, Rantala 1974). The method is based on the use of the normal intestinal flora of adult chickens. This preventive treatment has since been shown to be effective also against $S$. typhimurium infections in chickens (Nurmi et al. 1976, Lloyd et al. 1977). The caecal contents of an adult chicken can be anaerobically cultivated in such a way that the preventive effect of the flora will be maintained by the culture broth. This broth can be used on farms for the preventive treatment of young chickens (Nurmi et al.).

The purpose of the present study was to investigate the epidemiological factors affecting the outbreak of $S$. infantis infection on Finnish broiler farms in 1975-76.

\section{MATERIALS AND METHODS}

Broiler chicken production in Finland is concentrated in the south-western part of the country. The locations of the breeding farms of the four chicken-producing firms affected, A (16 farms), B (10 farms), C (14 farms) and D (11 farms), are shown in Fig. 1. A total of 349 flocks were studied. The time interval between the hatching and slaughtering of a flock was about six weeks. The number of flocks per year on different farms varied from three to 28, the average being about 10 flocks. Varying by farm, one-five flocks of different ages were reared simultaneously in separate chicken houses. Birds of different ages were never reared together in the same flock. Firms C and D had their own hatcheries. The parent birds had originally been obtained from a separate hatchery $(H)$, which directly supplied young chicks to the farms of companies $A$ and $B$.

The study took place from July 1,1975 to June 30,1976 . July 1975 was chosen for the first month of the study because the 
beginning of July was considered as still belonging to the preepidemic period.

A questionnaire was sent to each farm, requesting the following data: origin of chickens and feed, flock size, flock-specific mortality, the number of salmonella samples taken on the farms and from the animals at slaughter, and the number of positive samples. A flock was considered to be infected if any of the salmonella samples was positive. Sampling on farms was based on official recommendations (Broilerisalmonelloosityöryhmä 1972), according to which at least two samples of droppings per one thousand birds should be taken at the ages of two and five weeks, to be analysed for salmonella in an approved laboratory. Slight practical variations occurred between the farms studied, in the frequency of sampling. In the slaughter-houses, tissue or swab samples from the rectal area as well as liver samples were taken for salmonella analysis. The actual practice of sampling differed between the companies, a fact which lowers the value of these data for comparative purposes. Company B examined approximately five slaughtered birds per 5000, while company A took 20 samples. Each firm had its own microbiological laboratory for this voluntary salmonella control. A method of the Nordic Committee on Food Analysis (1969) was followed in all the laboratories. Technical data about the use of the preventive method were also requested. The form included questions concerning the handling and storage of the culture and the practical treatment procedure.

The preventive method, which has been described in more detail elsewhere (Seuna et al. 1978), was a slight modification of the one used by Rantala \& Nurmi (1973). The chickens were treated as soon as they arrived in the chicken house. The grower firms selected the flocks which would be treated with the bacterial culture. The use of the broth was started on those infected farms on which a recently preceding infection had been confirmed. Later some farms with no earlier known S. infantis infections were also included. The bacterial cultures delivered to the farms were analysed in our laboratory for the presence of salmonella and sulphite-reducing clostridia, using the methods of the Nordic Committee on Food Analysis (1965, 1969). In order to avoid the possible dissemination of diseases such as avian encephalomyelitis through the culture broth, the intestinal contents of clinically healthy birds were used for its preparation. 
The cultures delivered to the farms were proved free of salmonella. Other diseases inclined to spread through the broth are considered not to be of significance in Finland.

Chi-square test and regression analysis were used for the statistical analysis of the data.

\section{RESULTS}

The locations of the broiler farms and the month of the first isolation of S. infantis in their flocks are shown in Fig. 1. No data were obtained for six farms of firm $A$ and for one farm of both $B$ and C. Nine farms of firm D merely reported having always been free of salmonella.

No special pattern can be seen in the geographical spread of the disease within or between firms A, B and C (Fig. 1). The occurrence of S. infantis on the farms of firm D, located in a separate area, was considerably lower than on those of the other producers. Outbreaks of apparently endemic S. infantis infection in the birds of a certain farm of firm $D$ had been reported intermittently since 1971 . Another farm of the same company became infected, after a flock of young chickens was purchased from hatchery $\mathrm{H}$ in September 1975. Since then S. infantis had been found on this particular farm. This finding, though not conclusive, suggests a role for the hatchery or the supply flocks in the epidemic.

The monthly incidence of infected flocks during the study period is shown in Fig. 2. No data concerning the sampling and occurrence of salmonella were given for 15 flocks on the farms of firm B and for one flock of firm A. From the beginning of 1976 separate percentages were calculated for flocks receiving the preventive treatment and for non-treated flocks. In January 1976 only two flocks were treated. On the basis of the data (Fig. 2), the onset of the epidemic cannot be ascertained. An epidemic situation was found to prevail already in the first month of the study.

The proportion of infected flocks was greatest in December 1975. After that, the epidemic curve declined, except for a rise in the last month of the study. The curve represents the pooled data of firms A, B and C. Firm D has been omitted, because its data were incomplete. No data were given concerning the number of flocks reared on the non-infected farms of that firm. The incidence of infected flocks belonging to each of the firms A, B 


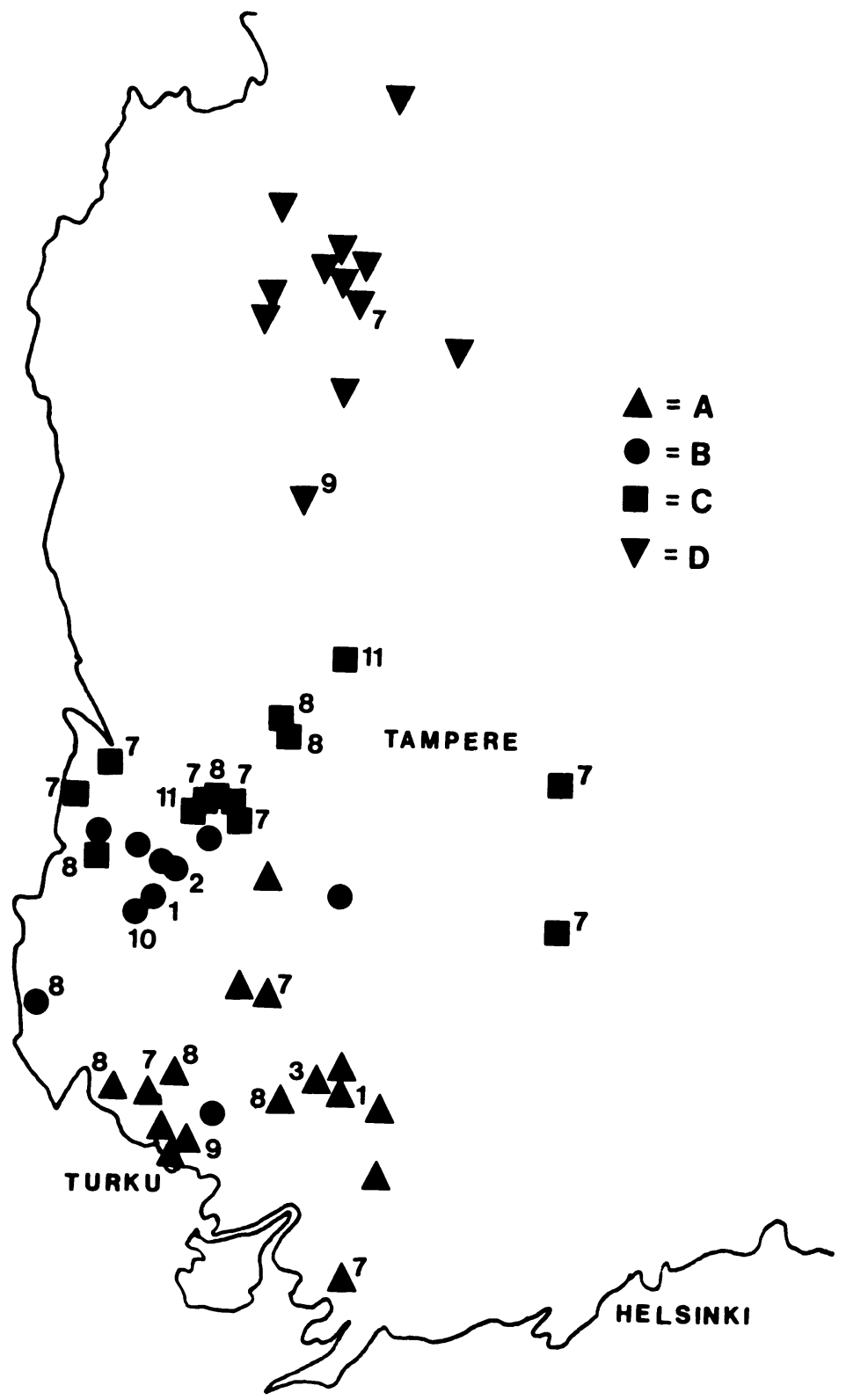

F ig u r e 1. Locations of the broiler chicken breeding farms of the four companies studied (A, B, C and D). The number indicates the month of the first isolation of $S$. infantis on each farm. 


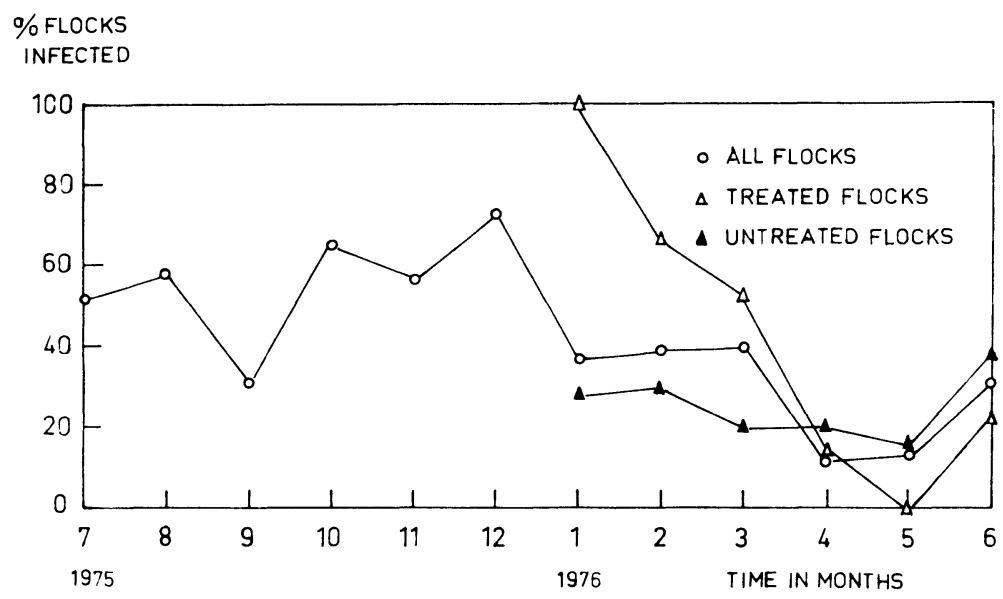

F i g u r e 2. Monhtly percentage of flocks infected with S. infantis between July 1, 1975 and June 30, 1976. The figure represents the pooled data of the companies A, B and C (Fig. 1).

and $\mathrm{C}$ is shown in Fig. 3. The decline of the epidemic curve for all untreated flocks (Fig. 2) mainly reflects the fact that the prevalence of salmonella infection declined in firm $\mathrm{C}$ without treatment. Subsequently the epidemic curve of firm A also declined, but the epidemic still continued on its farms at the end of the study period. The situation on the farms of firm $B$ remained constant during the study.

The occurrence of $\mathrm{S}$. infantis positive flocks on the farms of companies $A$ and $C$ is shown in Figs. 4 and 5. There were con-

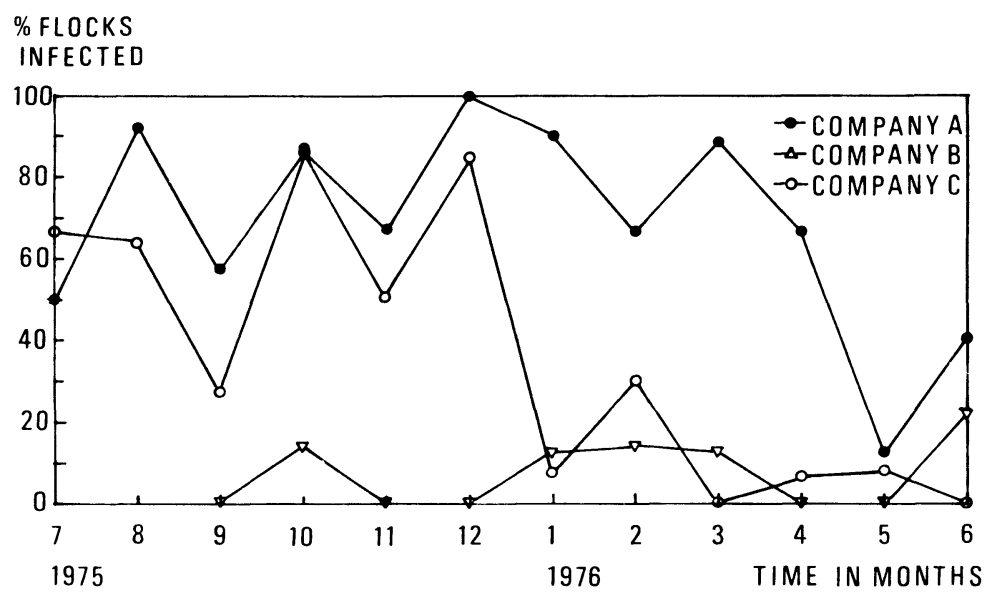

Figure 3. Monthly percentage of flocks infected with S. infantis on the farms of the companies A, B and C separately. 


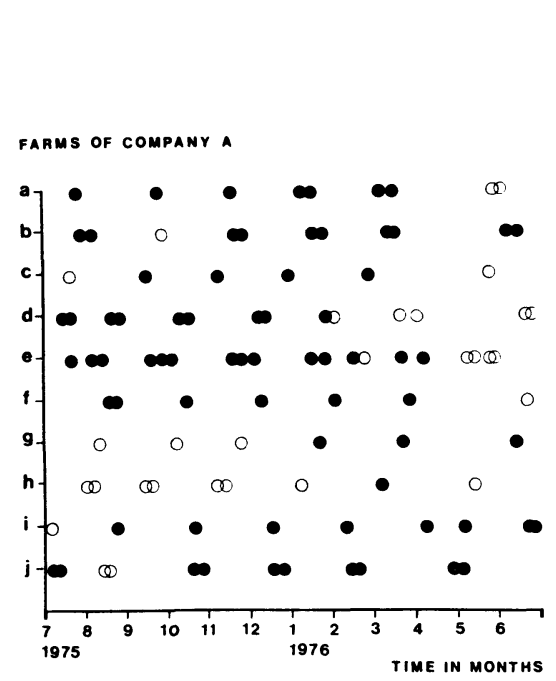

Fig u re 4. Occurrence of S. infantis infection on the farms of company A. The flocks are plotted according to the date of arrival at the farm.

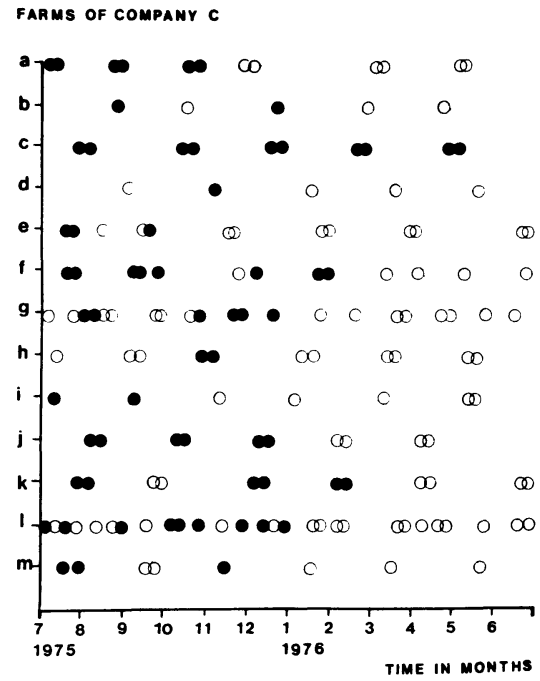

Fig u r e 5. Occurrence of S. infantis infection on the farms of company $\mathrm{C}$. The flocks are plotted according to the date of arrival at the farm.

Flock found to be S. infantis positive in later examinations

$O$ Flock with no isolation of $S$. infantis

siderable differences in the spreading pattern of the epidemic on farms within a company and between companies. The proportion of infected flocks on the farms varied from one infected flock to all flocks infected. Some farms became infected in the beginning of the study period and later got rid of the infection, while others became infected at the very end of the period. Some farms appeared to have been intermittently infected.

Feeds from five different manufacturers were used on the farms. The distribution of $\mathrm{S}$. infantis positive and negative flocks according to the origin of the feed used is shown in Table 1. A highly significant statistical difference in the infection rate $(\mathrm{P}<0.001)$ exists between the flocks receiving feeds III and $\mathrm{V}$ on the one hand and those receiving feed $I$ on the other (Table 1 ). Feeds II and IV were used in so few chicken flocks that a statistical analysis could not be made. Flocks which had been fed with more than one feed were excluded. The farms of company A use 
T a ble 1. The occurrence of salmonella infection in broiler chicken flocks on the farms of companies A, B and C according to their feeding history. Flocks fed with more than one feed were excluded.

\begin{tabular}{lccccr}
\hline & \multicolumn{5}{c}{ Feed manufacturer } \\
\cline { 2 - 6 } & I & II & III & IV & V \\
\hline $\begin{array}{l}\text { Number of S. infantis } \\
\text { positive flocks }\end{array}$ & 52 & 2 & 48 & 7 & 12 \\
$\begin{array}{l}\text { Number of S. infantis } \\
\text { negative flocks }\end{array}$ & 126 & 10 & 21 & 5 & 11 \\
\hline
\end{tabular}

mainly feeds III and V, while B uses feeds I and III. Most of the farms of company $C$ use mainly feed I and the farms of company $D$ purchase I, II and IV. Some farms use feeds from more than one manufacturer. The relatively high infection rate even among the flocks receiving feed $I$, and the frequent use of more than one feed, do not allow the drawing of positive conclusions as to the role of a specific feed as the source of the epidemic.

No statistical difference was found in the incidence of salmonella infection between the flocks connected with hatcheries $\mathrm{C}$ and $\mathrm{H}$. There was a statistically significant difference $(\mathrm{P}<0.05)$ between companies $A$ and $B$ as well as $A$ and $C$ in the incidence of S. infantis infection.

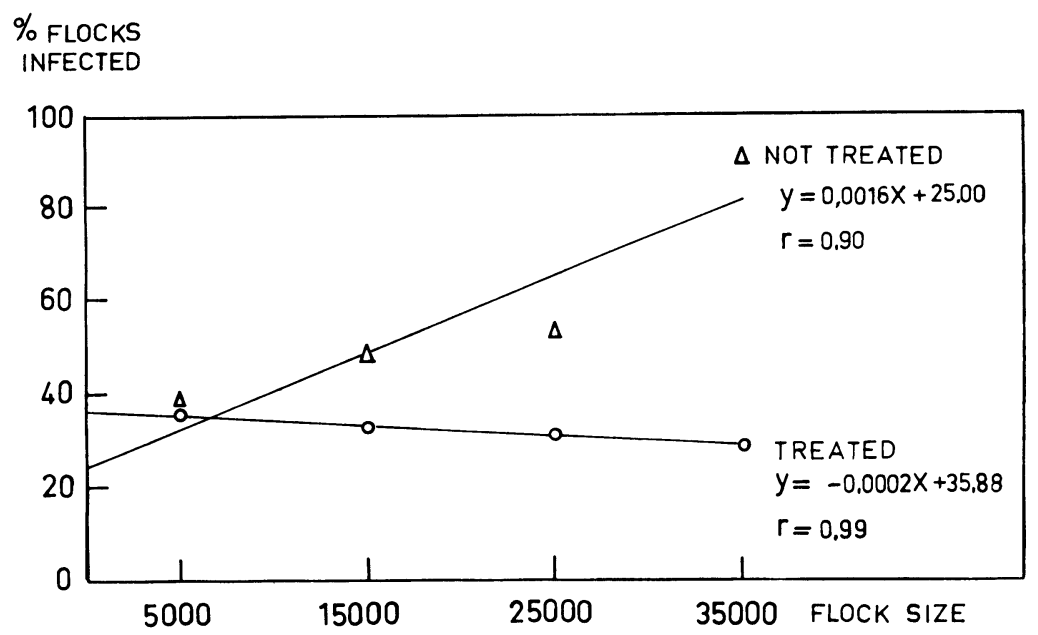

F i g u r e 6. The effect of flock size and the preventive treatment on the infection of $\mathrm{S}$. infantis in broiler chickens on the farms of companies $\mathrm{A}, \mathrm{B}$ and $\mathrm{C}$. 
T a b l e 2. Effect of the preventive treatment on the occurrence of S. infantis in samples taken from the infected flocks of broiler chickens of company $A$.

\begin{tabular}{lcccc}
\hline & $\begin{array}{c}\text { Number } \\
\text { of flocks }\end{array}$ & $\begin{array}{c}\text { Number of } \\
\text { salmonella } \\
\text { negative } \\
\text { samples }\end{array}$ & $\begin{array}{c}\text { Number of } \\
\text { salmonella } \\
\text { positive } \\
\text { samples }\end{array}$ & $\begin{array}{c}\text { Percentage of } \\
\text { salmonella } \\
\text { positive } \\
\text { samples }\end{array}$ \\
\hline $\begin{array}{l}\text { Untreated } \\
\text { Treated }\end{array}$ & 40 & 677 & 508 & 42.8 \\
\hline
\end{tabular}

The regression lines, constructed for grouped data, between the number of chicken in a flock and the proportion of infected flocks for both treated and untreated birds on the farms of companies A, B and C are shown in Fig. 6. The larger the flock, the more frequently it was demonstrated to be infected. The statistical significance of the correlation coefficients is $\mathrm{r}=0.90, \mathrm{P}=0.1$ (not significant); $\mathrm{r}=0.99, \mathrm{P}=0.01$ (highly significant).

The positive effect of the microbiological preventive treatment improved when the flock size grew. This phenomenon is probably due to the more modern facilities and equipment in the large new farm houses, which ensure the correct and more effective application of the broth.

The effect of the preventive treatment on the frequency of S. infantis positive samples at slaughter among the birds of company $A$ is shown in Table 2. The use of the preventive treatment seemed to increase the resistance of the birds to $S$. infantis in the infected flocks of company $A$. The association between the treatment of chicks and the decline in the frequency of salmonella in the flock samples is statistically highly significant $(\mathrm{P}<0.001)$.

The effect of the preventive treatment on the occurrence of S. infantis positive flocks is shown in Table 3. The proportion of infected flocks was lower when the treatment was used. This

Table 3. Effect of the preventive treatment on the occurrence of S. infantis in broiler chickens of companies A, B and C.

\begin{tabular}{lccc}
\hline & $\begin{array}{c}\text { Number of } \\
\text { salmonella } \\
\text { negative flocks }\end{array}$ & $\begin{array}{c}\text { Number of } \\
\text { salmonella } \\
\text { positive flocks }\end{array}$ & $\begin{array}{c}\text { Percentage of } \\
\text { salmonella } \\
\text { positive flocks }\end{array}$ \\
\hline $\begin{array}{l}\text { Untreated } \\
\text { Treated }\end{array}$ & 141 & 125 & 46.8 \\
\hline
\end{tabular}


Table 4. Effect of S. infantis infection on mortality in broiler chicken flocks studied.

\begin{tabular}{lccc}
\hline & \multicolumn{3}{c}{ Mortality in flocks } \\
\cline { 2 - 4 } & $<3 \%$ & $3-6 \%$ & $>6 \%$ \\
\hline $\begin{array}{l}\text { S. infantis positive flocks, } \\
\text { number }\end{array}$ & 34 & 55 & 9 \\
$\begin{array}{l}\text { S. infantis negative flocks, } \\
\text { number }\end{array}$ & $(34.7)$ & $(56.1)$ & $(9.2)$ \\
$(\%)$ & 36 & & 48 \\
& $(21.1)$ & $(50.8)$ & $(28.1)$ \\
\hline
\end{tabular}

association between the use of the preventive treatment and the incidence of infection in the flocks is not statistically significant $(0.05<\mathrm{P}<0.1)$.

The effect of S. infantis infection on mortality rates in broiler chicken flocks is shown in Table 4, and the effect of the preventive treatment on mortality in Table 5. No significant differences were found in mortality rates between salmonella positive and negative flocks. Mortality was slightly higher in treated flocks than in untreated ones. The difference was not statistically significant.

Table 5. Effect of the preventive treatment on mortality in the broiler chicken flocks studied.

\begin{tabular}{lccc}
\hline & \multicolumn{3}{c}{ Mortality in flocks } \\
\cline { 2 - 4 } & $<3 \%$ & $3-6 \%$ & $>6 \%$ \\
\hline $\begin{array}{l}\text { Untreated flocks, } \\
\text { number } \\
(\%)\end{array}$ & 64 & 112 & 46 \\
$\begin{array}{l}\text { Treated flocks, } \\
\text { number }\end{array}$ & $(28.8)$ & $(50.5)$ & $(20.7)$ \\
$(\%)$ & 6 & 30 & 11 \\
\hline
\end{tabular}

\section{DISCUSSION}

One important problem relating to this epidemic is whether the infection was transmitted to the farms continuously from a particular source. The spreading of the infection could also have occurred during a short period prior to the beginning of the study period, after which the infection could have persisted in the surroundings of the farms and caused reinfection. There is 
evidence for both of these patterns of spreading. Not all of the infected farms were infected before the beginning of the study; the spreading happened gradually, especially on the farms of companies $A$ and B. Several farms were found to be infected intermittently. It was not possible to ascertain whether the new infection came from the surroundings or from a source outside the farm. On the two infected farms of company $D$ the former situation seems more probable. In firm $\mathrm{C}$ there was probably a common source of infection in the beginning of the study period, but the farms got rid of the infection during the study.

Contaminated feed was shown to have been an important factor in the spread of $\mathrm{S}$. infantis in cattle and chickens during the 1971 epidemic (Vasenius \& Jahkola 1976). Isolations of S. infantis have also been made from feeds III and $V$, in use during this study period ( $K$. Vasa, personal communication). These isolations were made by company $A$. The positive samples had been taken from farm silos after a storage period of two weeks. On the other hand, the feeds of these two manufacturers are also commonly used by the producer that suffered the epidemic only caused by S. typhimurium var. copenhagen (Seuna et al. 1978). Feed I was mostly used by companies $C$ and $D$; the former suffered a large epidemic, whereas the latter almost totally avoided one. The raw materials used in chicken feeds are known to contain salmonella, but the organisms are supposed to be destroyed in the manufacturing process. Thus, theoretically, the number of salmonella in the actual feed is expected to be very small. Thus, theoretically, salmonella in the actual feed can be excepted to be non-existent or very few in Finland at present. The official control has not found any positive samples. However, there is always the possibility of batches of contaminated feed passing the present type of official control based on sampling. The feed can also be contaminated after processing. The present study provides no evidence that the feed of one or more manufacturers, at least alone, might have been responsible for the epidemic.

An infection that spreads through the hatcheries is more difficult to prevent than one spreading through contaminated feed or subsequently through the environment. The animals will be infected when their resistance is low and undeveloped. The microbiological treatment used in this study has only little effect if any, if a bird has acquired the infection before treatment (Seuna et al.). The relatively weak effect of the treatment 
on the farms of firm A supports the hypothesis that at least in some cases the birds had been infected prior to the treatment. Some additional data received regarding firm B appeared paradoxical. Samples taken from the farms were seldom positive for S. infantis, but the deep-frozen products of the firm when analysed by municipal food laboratories were shown quite often to be contaminated by the organisms. Sampling in the slaughterhouse of this producer was done less frequently than in those of firm $A$, thus lowering the probability of finding an infected flock. Thus, in spite of the apparently conflicting results from firm B, the possibility that the infection may have spread through hatchery $\mathrm{H}$ cannot be excluded. There was no data available regarding salmonella control in parent flocks and the three hatcheries in the study.

Contamination of a flock direct from the environment, through the farm personnel or from animal sources such as wild birds and rodents, is also possible. This type of infection, however, would remain sporadic. The environmental factors mentioned can serve as reservoirs of salmonella on farms and lead to failure of cleaning and sanitation procedures because of immediate reinfection. This route of infection can be blocked using the preventive treatment on every flock entering the farm. The slaughter-houses may also spread the disease from farm to farm through contaminated transport boxes. The actual hygienic quality of the boxes was not evaluated in this study. The boxes were washed and desinfected at the slaughter-houses in order to eliminate this well-known route of disease spreading.

Broiler chickens are grown in large flocks where the animal density is high. The conditions for rapid growth and distribution of salmonella throughout a farm are very good. That is why even a few birds contaminated with $\mathrm{S}$. infantis can quickly infect the whole flock (Snoeyenbos et al. 1969). Also the probability of introducing the bacterium into a large farm through contaminated feed or infected young chickens is greater than in the case of a small farm. The treatment, however, was more effective with big flocks than with smaller ones. This may be due to the more modern equipment in big chicken houses and the more effective application of the broth.

The results of this study indicate that the preventive treatment has been considerably less effective in practical farm circumstances than in our laboratory (Rantala 1974, Nurmi et al. 
1976). Firm D was an exception. Both infected farms were immediately freed from the infection after introduction of the preventive method. The reduction of the frequency of $S$. infantis infection in chicken flocks (Table 2) is an important effect of the treatment. This has also been observed in our earlier field studies (Nurmi et al.).

A slight increase in flock mortality was found when the broth was used (Table 5). This finding can be explained by the fact that the treatment was mostly used on problem farms, where evidently other factors increased flock mortality. The limitation of feed and pure water during the treatment may have had undesirable effects, which, however, were not observed during previous laboratory studies (Nurmi \& Rantala 1973, Rantala \& Nurmi 1973, Rantala, Lloyd et al. 1977). The treatment did not seem to affect the growth of the birds. No major poultry diseases occurred in the farms during the study period. In some flocks respiratory infections were diagnosed, but there is no evidence that the infection could have been spread by the broth.

Several factors may have affected the spread of the disease. More attention should be paid to keeping parent flocks and hatcheries free of salmonella. The bacteriological control of chicken feeds should be effective. The microbiological preventive method can be practiced, with the effect of successfully defending against infection or reducing its level in broiler chicken flocks.

The epidemiological features of $S$. infantis infection in Finnish broiler chickens could not be fully explained on the basis of the results of this study. The lack of detailed records and a certain heterogeneity in record-keeping on the farms was found to be one limiting factor in this retrospective study.

\section{REFERENCES}

Broilerisalmonelloosityöryhmä: Komiteanmietintö. (Report of the official working group on broiler salmonellosis). No. B 49, Valtion painatuskeskus, Helsinki 1972.

Lloyd, A. B., R. B. Cumming \& R. D. Kent: Prevention of Salmonella typhimurium infection in poultry by pretreatment of chickens and poults with intestinal extracts. Aust. vet. J. 1977, 53, 82-87.

Nordic Committee on Food Analysis: Determination of the number of sulphitereducing clostridia in foods. Method no. 56, Teknisk Forlags Trykkeri, Copenhagen 1965.

Nordic Committee on Food Analysis: Salmonella bacteria. Detection in foods. Method no. 71, Teknisk Forlags Trykkeri, Copenhagen 1969. 
Nurmi, E. \& M. Rantala: New aspects of Salmonella infection in broiler production. Nature (Lond.) 1973, 241, 210-211.

Nurmi, E., E. Seuna \& M. Raevuori: Prevention of salmonellosis in broiler chickens by the flora of the alimentary tract of chickens. Rep. 2nd Congr. Int. Soc. Animal Hygiene, Zagreb 1976, 389394.

Rantala, $M .:$ Cultivation of a bacterial flora able to prevent the colonization of Salmonella infantis in the intestines of broiler chickens and its use. Acta path. microbiol. scand. Sect. B, 1974, $82,75-80$.

Rantala, M. \& E. Nurmi: Prevention of the growth of Salmonella infantis in chicks by the flora of the alimentary tract of chickens. Brit. Poultry Sci. 1973, 14, 627-630.

Seuna, E., M. Raevuori \& E. Nurmi: An epizootic of Salmonella typhimurium var. copenhagen in broilers and the use of cultured chicken intestinal flora for its control. Brit. Poultry Sci. 1978, $19,309-314$.

Snoeyenbos, G. H., V. L. Carlson, C. F. Smyser \& O. M. Olesiuk: Dynamics of Salmonella infection in chicks reared on litter. Avian Dis. $1969,13,72-83$.

Vasenius, H. \& M. Jahkola: Contaminated soya fodder as a source of Salmonella infantis epidemics in Finland. Rep. 2nd Congr. Int. Soc. Animal Hygiene, Zagreb 1976, 385-388.

\section{SAMMANDRAG}

Salmonella infantis epidemin hos finska broilers år 1975-76.

I artikeln beskrivs en omfattande epidemi hos broilers förorsakad av S. infantis. Tre av fem broilerproducerande företag i Finland drabbades. Infektionen spreds på kort tid sommaren 1975 till varje företags uppfödare. Ursprunget till infektionen och spridningssättet kunde inte klarläggas. Vissa epidemiologiska fakta pekade på en kläckningsanstalt som en eventuell spridare av sjukdomen. En foderkontamination kan också ha förekommit fastän resultaten i detta arbete inte $\mathrm{i}$ högre grad stöder möjligheten att fodret skulle ha varit den huvudsakliga smittoförmedlaren i denna epidemi.

En mikrobiologisk preventiv metod, baserad på användandet av en kultur från tarmfloran av fullvuxna broilers, tillämpades av många uppfödare. Följande sammanfattning kunde göras på basen av behandlingens resultat: en sänkning av antalet infektiösa grupper hos uppfödarna samt en signifikant sänkning av infektionsnivån hos S. infantis positiva grupper kunde konstateras.

(Received January 25, 1978).

Reprints may be requested from: M. Raevuori, the State Veterinary Medical Institute, P. O. Box 368, 00101 Helsinki 10, Finland. 